\title{
The Swedish Schools Inspectorate's View of Swedish Schools
}

\author{
Lisbeth Lindström $^{1} \&$ Solange Perdahl ${ }^{1}$ \\ ${ }^{1}$ Department of Culture, Communication and Learning, Luleå University of Technology, Luleå, Sweden \\ Correspondence: Lisbeth Lindström, Department of Culture, Communication and Learning, Luleå University of \\ Technology, Luleå, SE-971 87, Sweden. E-mail: Lisbeth.Lindstrom@ltu.se
}

Received: June 4, 2014

Accepted: June 16, $2014 \quad$ Online Published: July 3, 2014

doi:10.5539/jel.v3n3p15

URL: http://dx.doi.org/10.5539/jel.v3n3p15

\begin{abstract}
The purpose of this article is to shed some light on and give some examples of how the Swedish schools have interpreted their mission of educating young people and preparing them for the role of active citizens. More specifically, we are interested in how the "good" or "aspirational" school is presented in the reports published by the Swedish Schools Inspectorate. Our departure point will be the inspection work conducted by the Swedish Schools Inspectorate between 2009 and 2012. The selection of data is based on our wish to highlight supervisory reports, quality audit reports and targeted inspection reports. Another selection principle has been that not only municipal schools, but also independent schools, had to be represented among the analysed documents. Five of the reports are quality audit reports, two are the result of targeted inspections, and finally we have analysed one supervisory report. The results indicate that the aim of improving the pupils' knowledge results is a high priority for the Inspectorate, as is the goal to ensure all children and pupils' equal rights to a good education in a safe and stimulating environment, and to develop their civic skills. The analysed reports show that the inspections have revealed inadequate fulfilment of all these goals. Whether school inspections can functionally contribute to fulfilling the goal of educational equality, improving the knowledge of Swedish pupils and helping them develop into good citizens is debatable. On the one hand, the auditing function in itself constitutes a threat to the school operations developing a sense of judgement that would allow for reflections beyond the concept of effectiveness, and on the other hand the audits may, paradoxically enough, liberate the strength to question the discursive dominance of the Swedish Schools Inspectorate, shaped by systemic world logic, and thereby achieve an independent development.
\end{abstract}

Keywords: Swedish schools inspectorate, curricula, NPM, Sweden, quality audit reports

\section{Introduction}

The Swedish school system has gone through a number of changes since the late 1980s. The focus of these reforms has been municipalisation, i.e., the transfer of principal responsibility for the school from the state to the municipalities. Other characteristics are increased freedom of choice, management by objectives and the possibility to establish independent schools. Management by objectives had its breakthrough in the early 1990s, and led to a transition within the national school system from management by regulated resource allocation to management by objectives and results.

The independent schools, under other responsible authorities than the municipalities, were intended as a supplement to the municipal schools. The government was hoping that this reform would contribute to a more cost-effective system, as the schools would be given room to specialise, while being encouraged to develop new and more efficient working methods. One of the key words was choice; pupils making free market choices is expected to eliminate non-competitive actors, which in turn is expected to increase the quality of Swedish schools. To survive on the market, schools have to offer a selection that is attractive to presumptive pupils. The market-oriented school system had been born.

In 2010 and the years thereafter, the reformation of the Swedish school system has continued, and can be described as the most extensive in decades. The first of July 2011, a new Education Act was introduced (SFS 2010: 800). A number of new curricula were adopted: Curriculum for the preschool Lpfö98, revised (2010), Swedish National Agency for Education (2010); Curriculum for the compulsory school system, the preschool class and the recreation centre Lp11, Swedish National Agency for Education (2011a), as well as Curriculum for the upper secondary school Gy11, Swedish National Agency for Education (2011b). In addition, a new 
Education Ordinance (SFS 2011: 185) was adopted along with the introduction of a new grading scale for compulsory school, (SKOLFS 2011: 157), and for the upper secondary school (SKOLFS, 2011: 145). Along with all these reforms, it was also decided that it would be obligatory for newly hired headmasters to pass a headmaster training programme (SFS 2009: 1521). This means that municipalities, county councils and the responsible authorities of the independent schools must ensure that all headmasters in their employment as of March 2010 participate in a headmaster training programme or the equivalent.

These reforms of the Swedish school system over the last decades can be traced back to neoliberal tendencies, which according to Lahlema and Beach "[...] implies: more exact evaluation, competition, individualization, increasing choice and criticism against social democratic politics for inflexibility, inefficiency, increasing costs and falling standards" (Lahlema \& Beach, 2003, pp. 2-3). The management mentality that tends to fit this description, and which has been perceived as an ideological battering ram, is called New Public Management (NPM). The ideas behind these reforms come from the business world, modelled on company organisation and management. Decentralisation, competition, transition from regulatory intervention to management by objectives and results, and an increased focus on quality control are central concepts of New Public Management. The internal logic that governs NPM has led to an increased need for quality control, where concepts like auditing and accountability have to be institutionalised, which is exactly what happened in Sweden in 2008 with the establishment of the Swedish Schools Inspectorate, a new Swedish authority under the Ministry of Education and Research.

The Swedish Schools Inspectorate is a national administrative authority and the supervisory authority of the entire school system; from preschool to adult education. The Swedish Schools Inspectorate works with different inspection activities, such as regular supervision, quality auditing, targeted supervision as well as licensing. The regular and targeted supervision is intended to ensure that the school/operation is working in accordance to applicable laws and regulations. The inspections are carried out to contribute to the development of the schools, by highlighting important development areas; this reactive approach is thus to provide the conditions for the proactive quality efforts of the schools. The Swedish Schools Inspectorate also assesses licence applications and independent schools' entitlement to funding.

The idea that the school system can be developed through inspection is no new concept in Swedish education policy, having come up now and again in various organisational forms since the late 1800s. As of 2003, Sweden has an extensive organisation for school inspections, and since 2009, the Swedish government has reserved resources equivalent to more than 300 annual work units for the purposes of school inspection (Thornberg \& Thelin, 2011). The establishment of the Swedish Schools Inspectorate may, according to Ekholm and Lindvall (2008), be seen as a logical result of an impatient government questioning the way the municipalities, as the responsible authorities of a decentralised operation, managed the schools by objectives and results. The audits carried out by the Swedish Schools Inspectorate are a form of recentralisation. The Ombudsman for Children (BEO) is part of the Swedish Schools Inspectorate. Children and pupils who feel their rights have been violated in childcare or school (or by their parents) can turn to the BEO. This can relate to incidents between pupils, but also to pupils feeling that their rights have been violated by adults at the school. The BEO mandate is founded on the Swedish Education Act (SFS, 2010: 800, Chapter 6) and the Swedish Discrimination Act (SFS, 2008: 567) $\mathrm{BEO}$ investigates reports of violations that do not constitute discrimination, and along with the Equality Ombudsman (DO), BEO works to prevent violations, discrimination and harassment of children and pupils.

In light of NPM, all citizens are expected to take greater responsibility for their own welfare, while the role of the welfare state as the provider and supplier of welfare services has changed.

The purpose of this article is to shed some light on and give examples of how the Swedish schools have interpreted their mission of educating young people and preparing them for the role of active citizens. More specifically, we are interested in how the "good" or "aspirational" school is presented in the reports published by the Swedish Schools Inspectorate. Based on an interpretation of the Swedish Schools Inspectorate's audits, the aim is to reconstruct discourses that emerge regarding the aspirational school; the mission of which is to support young people in their transformation into active citizens.

Our departure point will be the inspection work conducted by the Swedish Schools Inspectorate between 2009 and 2012. The selection of data is based on our wish to highlight supervisory reports (1), quality audit reports (5) and targeted inspection reports (2). Another selection principle has been that not only municipal schools, but also independent schools, had to be represented among the analysed documents. Finally these documents have been selected because they have been found to be representative of school management by objectives and results. See 
Appendix 1 for a list of the eight reports. The empirical data is presented in more detail in the chapter on methodology and implementation.

The article is structured in the following way: under the headings "The core values of the Swedish school" and "The mission of the school and the preschool", we present different control instruments that the Swedish schools must relate to. The theoretical framework is presented under the title "General theoretical starting points", and thereafter comes a section on methodology and implementation. In the next section, with the title "The good school and/or top of the class", empirical data is presented followed by a discussion and conclusion.

\subsection{Core Values of the Swedish School}

The core values of the Swedish schools and preschools are found in the curriculum for each school form; Lpfö98, (Skolverket, 2010), Lp11, (Skolverket, 2011a) and Gy11, (Skolverket, 2011b). These curricula state that the preschool and the school system are based on democratic values. They mention the core values and mission of the preschool and the school. In the curriculum for the compulsory school system, the preschool class and the recreation centre (Lp11), and the curriculum for the upper secondary school (Gy11), it appears that the education system is intended to help pupils obtain and develop knowledge and values (Skolverket, 2011b). These curricula refer to the Education Act (SFS 2010:800), which among other things determine that education is to convey and establish respect for human rights and fundamental democratic values that are the cornerstones of Swedish society. The 1998 preschool curriculum (Lpfö98) contains similar wording about the activities being designed in accordance with fundamental democratic values (Skolverket, 2010).

The Education Act (SFS 2010: 800) prescribes that education within each type of school is to be the same irrespective of where in the country it is provided. The national objectives in each curriculum provide specific equivalence norms. The curricula clarify that an equivalent education does not mean that education has to be designed exactly the same in all parts of the country, or that school resources have to be distributed evenly (Gy11 \& Lp11, Skolverket, 2011a-b). From these texts it is evident that consideration must be given to the different conditions, needs and knowledge levels of the pupils, and that there are different methods to obtain these objectives. It is also clear that particular attention should be paid to the pupils who, for various reasons, have difficulties in obtaining the educational targets, and that the school has a particular responsibility for pupils with functional disabilities. It is thus impossible to model the education in the same way for everyone.

Similar wording is also found in the 1998 preschool curriculum (Lpfö98), which states that the preschool, regardless of where in Sweden it is located, must work to achieve the objectives set for the educational activities. It mentions care for the well-being, security, development and learning of the individual child, and that these aspects are to characterise the work in preschools. The preschool too must consider the different conditions, needs and knowledge levels of the pupils, and the fact that these aspects make it impossible to model the education the same way everywhere. Similar to the schools, the preschools have a compensatory task, which means that resources cannot reasonably be evenly distributed (Skolverket, 2010).

\subsection{The Commission of the School and Preschool}

The main task of the upper secondary school is to convey knowledge and to create the right conditions for the pupils to retain and develop this knowledge. The education is to promote the pupil's universal development into responsible adults who actively participate in and develop their professional and social settings (Gy11, Skolverket, 2011b). The curriculum also clearly states that the school's task is to transfer values, convey knowledge and create conditions for the pupils to retain and develop knowledge. Furthermore it is clear that the school is to communicate such permanent knowledge as provides the foundation for a common frame of reference in society, and which is based on fundamental democratic values and human rights. This corresponds to the wording of the Swedish Education Act.

The compulsory school curriculum is worded a little differently. The departure point is that the school is to collaborate with the family to promote the universal personal development of the pupils into active, creative, competent and responsible individuals and citizens (Lp11, Skolverket, 2011a). This text shows that education and upbringing is viewed in a deeper sense as a matter of transferring and developing a cultural inheritance, meaning values, traditions, languages and knowledge from one generation to the next. The school's task is to transfer fundamental values and to promote the pupils' learning, in order to thus prepare them for their future private and professional lives. "The school should impart the more unvarying forms of knowledge that constitute the common frame of reference that all in society need" (p. 9). One important stated task of the school is to provide general knowledge and put things into context. Collaboration with the home environment is also 
emphasised, and it is clear that the school must be a support to the families in their responsibility for the upbringing and development of the children.

In the 1998 preschool curriculum Lpfö98 (Skolverket, 2010), it is clear that activities are to be fun, safe and educational for all participating children. The pre-school should provide children with good pedagogical activities, where care, nurturing and learning together form a coherent whole. Play is emphasised as an important part of child development and learning. The importance of collaboration with the family is also underlined: children's development into responsible persons and members of society should be promoted in partnership with the home. The preschool commission involves developing the abilities and individual cultural creativity of each child, and to pass on a cultural heritage, in terms of values, traditions, history, language and knowledge from one generation to the next. To make this possible, the preschool is to consider the fact that children live in different home environments, and that children will try to understand, contextualise and discern meaning based on their own experience. "The pre-school should be a living social and cultural environment that stimulates children into taking initiatives and developing their social and communicative competence" (p. 9).

One section of the curriculum for the upper secondary school (Gy11, Skolverket, 2011b) contains the title "Knowledge and learning", which introduces the view of knowledge as something that can be expressed as facts, understanding, skills and familiarity. The text states that the knowledge acquisition of the pupils is dependent on whether they are provided with the tools to recognise connections and contexts. It determines that the school is to afford pupils the opportunity to gain general knowledge and put things into context. This is expected to happen through the school utilising the knowledge and experience of society, which the pupils have acquired, for example, through contact with working life. The curriculum for the compulsory school system, the preschool class and the recreation centre (Lp11, Skolverket, 2011a) contains the title "Good environment for development and learning", with the statement that the school is to strive towards creating the best overall conditions for pupil learning, reflection and knowledge acquisition. This section also points out that the foundations for a pupil's sense of security and self-esteem are established in the home, but that the school also has an important role to play in allowing the pupil to grow, make progress and overcome difficulties.

The 1998 preschool curriculum Lpfö98 (Skolverket, 2010) states that children seek and acquire knowledge through play, social interaction, exploration, creativity, observation, conversation and reflection. The preschool group is seen as an important and active part of development and learning. The activities at preschool should be based on the child's realm of experience, interests, motivation and thirst for knowledge. It furthermore states that the preschool is to contribute to children with a mother tongue other than Swedish having a chance to develop their Swedish language skills as well as their mother tongue. Learning in preschool must be based on both interaction between adults and children, and on the children learning from one another.

In conclusion, these curricula show that the preschool and national school system rest on a democratic foundation, and that concepts such as influence, inclusion and responsibility are central. It is also clear that pupils should receive an equivalent education within each type of school no matter where in the country it is provided, and that the education must be accessible and modelled on the individual conditions of the pupils. Through the analysed documents, we will interpret the depiction of how the school's commission has been carried out within select parts of the Swedish school system.

\subsection{Earlier Research and General Theoretical Starting Points}

Ekman (2007) argues that the democratic mission of the school to promote the pupils' desire to actively participate in society is now well-established, while she notes that the governing documents of the school system are vague in their descriptions of its objectives (Sandström, Kjellin, \& Stier, 2008). Rönnlund (2013) points out that the ability to exert influence on decision-makers is part of the civic democratic skills that the school must impart to the pupils.

The Swedish National Agency for Education (2011c) is also of the opinion that this is a matter of how the task of educating democratic citizens is interpreted and practically implemented in the classroom. According to Brunmark (2010), this can be less than simple, since efforts to educate can have various implications in terms of tension between increased pupil autonomy on the one hand, and varying degrees of teacher control on the other, which is necessary to fulfil the task at hand. In a similar way, Sjöberg (2009) points to international education policy tendencies that have affected the school's task of shaping individuals who are able to handle and take on growing responsibilities in modern society. More concretely this is interpreted as taking responsibility for one's own choices, education and professional possibilities. 
Sülke (2007) and Biesta, Lawy, and Kelly (2009) feel that civic education must begin by strengthening the pupils' sense of self and confidence. This can be done by allowing young people a voice, taking their opinions seriously and giving them influence. Fiehn (2007) provides a similar argument, saying that civic education is an important part of young people's development. By affording them the opportunity to learn about their rights and obligations as the starting point to understanding society, they can develop an active citizenship that prepares them for the challenges they will face later in life. Sandström, Kjellin, and Stier (2008) are of the opinion that the values and attitudes that are transferred and transformed in daily interactions take place to a large extent in the school, and that it is therefore essential to understand and monitor the teachers' own attitudes, values and actions. Carlsson (2006) notes that the attributes and provisions given to pupils will also influence the kind of citizens they become, and as such what they can contribute to social developments in the long term.

Concepts like citizenship and active citizenship are complex; they have several dimensions and can be studied from any number of perspectives (Olsson, 2013; Ekman, 2007; Rönnlund, 2013; Carlbaum, 2012; Carlsson, 2006). One example is Kjörholt (2004), who describes the way children construct their citizenships, while Lister (2007a; 2007) highlights how people interpret and negotiate their citizenship on an everyday basis, for example in terms of rights, obligations, belonging and participation. Hartsmar and Persson (2013) clarifies that civic skills are a basic knowledge that is best developed in democratic schools through democratic methods.

This article will focus on the Swedish school as a social practice, which in the terminology of Bourdieu (1973) can also be applied in relation to professional practice within a given field, i.e., the school. Broady (1991) points out that a social field is defined as "[...] a system of relations between positions of special agents and institutions who struggle for a common cause" (p. 266). To participate, the actors require resources, symbolic capital, that is recognised and accepted in the field.

The theoretical concepts of Bourdieu (1973) can be traced back to his anthropological studies of the Algerian agrarian society, and more specifically to his studies of how everyday social practices could be understood in relation to doxa. The doxa should be viewed as structures that limit social actions, as it indicates acceptable and unacceptable, as well as natural and unnatural acts. This process gives rise to a homogenous system of dispositions for our awareness, reflections and actions, which are successively incorporated into a habitus. An action can thus never be understood without being related to the doxa, which in itself creates a logic of norms and structures that set the direction of our habitus.

In this present study, the Swedish audited school can be seen as the body representing and defending the current order, or the orthodoxy, while the Swedish Schools Inspectorate, being relatively new to the field, is characterised as a heterodoxy. Järvinen (2007) would argue that "[...] the heresy of the newcomer forces the establishment to break its silence, and allow doxa to be crystallised into orthodoxy; a defensive discourse to preserve its monopoly" (p. 274). Those who have established an optimal amount of recognised capital in the field will fight to preserve that capital, and to make it infinitely valid in the field in question. The challengers on the other hand, in this case the Swedish Schools Inspectorate, are trying to break the status quo and establish new truths in the field. Not least is it possible to show a heterodoxal colonisation by market economics sprung from NPM, which encourages measurability and effectiveness, while the often immeasurable, unclear and at times ineffective is seen as an expression of the doxa.

In his theories on education, Bourdieu uses the concept of reproduction. Unlike socialisation, this concept is based on the idea of everyone having equal opportunities (Månsson, 1995). Bourdieu argues that this approach in practice results in an education that attempts to treat everyone equally, thus overlooking the fact that there is a transference within the education in question of the predominate social system of values and norms. Unless everyone is truly equal, this means overlooking or ignoring the fact that pupils come from different socio-cultural, and thereby socio-economic, backgrounds.

The mandate of the Swedish Schools Inspectorate, as described above, is to use the Education Act, curricula and other regulations to carry out regular supervision, quality audits, targeted supervision and licensing. The Swedish Schools Inspectorate can be interpreted and understood as a panopticon, i.e., an institution with an "all-seeing" eye. The Inspectorate uses different kinds of audits, both announced and surprise visits, and so the schools are not always able to anticipate when the inspection is to take place. As described by Foucault (1987), the authorities have thereby succeeded in making the schools internalise the disciplining gaze, resulting in a self-disciplinary behaviour based solely on the awareness that they can be audited.

The Swedish Schools Inspectorate as an institution should thus be seen as a tool of the sovereign power, as well as of the disciplinary power that shapes and reshapes the norms of the criteria that define quality in the schools. Foucault (1993) further argues that power is never distinguishable from knowledge; knowledge is the 
cornerstone of exerting power, while doing so also creates knowledge. "Every educational system is a political means of maintaining or of modifying the appropriation of discourse, with the knowledge and the powers it carries with it." (Foucault 1993, p. 31) The governing mentality of NPM, along with its principle of management by objectives and results, could, according to Alvesson (2002), be seen as equal to disciplines such as medicine, psychiatry and psychology, which are all dialectically related to social practice; in this article represented by the Swedish school system. Social practice maintains, constitutes and constructs the current hegemonic management discourse, which "[...] according to this view should be understood as an instrument of power, through which the scope of action for each individual is encircled and limited, rather than a form of "neutral" control and coordination" (p. 72). In terms of the ideas presented by Foucault (1993), the Swedish Schools Inspectorate can thus be seen as a body intended to maintain the sovereign power, and cannot be viewed as a body intended to impartially and objectively uphold the law since the governing mentality of NPM, which saturates the school as an institution, also influences what is to be audited; a selection that is far from objective. In addition to being a tool of the sovereign power, the Swedish Schools Inspectorate can thus be seen as a disciplinary power with the aim of shaping that which is seen as school norm, for example by suggesting certain techniques to handle problems in accordance with the discourse of NPM. Auditing, monitoring, evaluation and ranking systems would appear to be such techniques.

Habermas $(1984,1996)$ discusses the terms system and lifeworld, as well as the rationalities of these concepts, i.e., the possible motives or driving forces for different actions that may exist to achieve increased efficiency or understanding. Habermas argues that the systems tend to colonise the lifeworld, which is tied to entirely different principles, such as the establishment of understanding through values, norms and linguistic activities. He further suggests that the lifeworld and the communicative action, or dialogue, must be strengthened and constitute the basis of the systemic world and of purposive rational action (Habermas, 1984, 1996; Andersen, 2007). This article considers the Swedish Schools Inspectorate and the control instruments of the schools to be a function of the system, while headmasters, heads of preschools, teachers and pupils, despite of course being part of the same system, to a high degree adhere to the principles of the lifeworld as their work is based on the commission of the preschool and the school, which is to convey and establish respect for the human rights and fundamental democratic values that are the cornerstones of Swedish society. In this article the Swedish school system is considered part of an epistemological discourse (Foucault, 1993), with full awareness of the fact that discourse can be interpreted in any number of contradictory and overlapping ways (Winther, Jörgensen \& Philips, 2000). The discursive arena of this article consists of the selected texts. The point of departure here is that policy can be seen as discourse (Ball, 1994) and that text can be understood as a discursive and social practice that in turn can be put into educational context (Fairclough, 1992a-b).

\section{Methodology and Implementation}

Discourse analysis is a theoretical as well as a methodological approach (Westlind, 1996; Carlbaum, 2012). This article uses text analysis as a tool to review the texts, while discourse analysis is used as an analytical tool (Hellspong, 2001; Alvesson \& Sköldberg, 1994; Bergström \& Boréus, 2000). Our approach is critical analysis with an ambition to identify future needs of change (Winther-Jörgensen \& Philips, 2000).

Hellspong (2001) talks about interpersonal structure and the linguistic actions displayed in the text and the interaction that the text wants to involve its reader in. Gustavsson (2004) considers textual interpretation, which requires both language skills and perception, to take place in two steps: one intertextual interpretation, where different parts of the primary text are related to one another, and one contextual interpretation. The following documents have been included in the study: Supervisory Report (2013: 01), Supervision of Assessment and Grading, Swedish Schools Inspectorate (2013a), Targeted Inspection (Ref. no. 402-2013: 2272), Asylum-seeking Children's Right to an Education, Swedish Schools Inspectorate (2013b), Targeted Inspection Teacher support and working methods in independent upper-secondary schools, (Ref. no. 40-2013:180), (Swedish Schools Inspectorate, 2013c), Quality Audit, (2014: 1), Municipal Resource Allocation and Work Against the Negative Effects of Segregation in the Swedish School System, Swedish Schools Inspectorate (2014); Quality Audit, (2012: 9), The Schools' work with Democracy and Core Values, Swedish Schools Inspectorate (2012), Quality Audit, (2010: 10), Do the schools work systematically to improve the knowledge acquisition of the pupils? Swedish Schools Inspectorate (2010a), Quality Audit, (2010: 1), School Efforts in Cases of Harassment and Violations, Swedish Schools Inspectorate (2010b) and Quality Audit, (2009: 1) One in two to the finish line. On the (in)ability of the upper-secondary schools to get their pupils to complete their education, Swedish Schools Inspectorate (2009). Also refer to Appendix 1 for a list of documents. 
In order to highlight and give examples of how the Swedish schools have interpreted their mission, i.e., to educate young people and prepare them for the role of active citizens, the empirical data had been reviewed in two steps.

First, the primary texts have been read several times, noting the opinions expressed therein, the information they contain, and which summarising conclusions were drawn from the inspection.

The texts have then been interpreted through discourse analysis. The point of departure for this analysis is to study social phenomena by focusing on language, for which reason the analysis could to some extent be described as linguistics. The analysis also includes the discursive practice, where focus is on the selection of texts and how they are presented. Another interesting aspect has been how various expressions and concepts are presented in the texts; which words, arguments and thesis are used; which conclusions are drawn; which recommendations are given; and which perspectives and intentions are reflected in them (Fairclough, 1992a-b). Finally the material has been grouped and compiled in two discursive fields: The Mandate of the Swedish Schools Inspectorate and The Aspirational School.

Our approach is to use abductive reasoning, and through our theoretical framework, we have found central concepts to form our filter when reviewing the empirical material.

\section{The Good School and/or Top of the Class}

In the material that we have studied, there is a discursive, social and cultural practice present (Fairclough, 1992a-b). We consider the selected texts as having been produced based on a social and cultural practice, i.e., the school, and then compiled in official reports published by the Swedish Schools Inspectorate.

In this chapter, we account for the results of our textual analysis of the empirical material. The chapter is structured based on the two discursive fields that appeared through the textual analysis; The Mandate of the Swedish Schools Inspectorate and The Aspirational School. Within each discursive field, we provide quotations from the empirical material. We have named the respective discourses "The Mandate of the Swedish Schools Inspectorate" and "The Aspirational School-possibilities and obstacles". The texts have been analysed in the order provided in Appendix 1, and the below account follows the same structure.

\subsection{The Mandate of the Swedish Schools Inspectorate}

The Swedish Schools Inspectorate is commissioned by the Swedish government and its tasks include auditing all school-related activities in the country. Its mandate consists, among other things, of auditing the quality of such education and pedagogical activities as falls under its supervisory authority. Auditing refers to the detailed and systematic investigation of operational quality within a delimited area, in relation to goals and guidelines. "The point of departure is the equal right of all children and pupils to a good education in a safe and stimulating environment" (Swedish Schools Inspectorate, 2014, p. 5). The main objective of the quality audit is said to be contributing to development. "The audit clarifies what improvements need to be made in order to reach the operational objectives within the area in question to a greater extent. The purpose is also to describe aspects that work well, and to indicate success factors" (p. 5). In addition, the audits of the Swedish Schools Inspectorate are expected to yield results in the form of documentation to indicate improvement measures also to those responsible authorities that have not been subject to audits.

The Swedish school system implements what is referred to as national tests. The assessment and grading of these tests is part of the teacher's work. The Swedish Schools Inspectorate has been tasked with conducting a certain amount of central grading each year of national tests that have been given in the Swedish primary, secondary and upper-secondary schools. The aim of such central grading is primarily to support a uniform assessment and grading of these tests across the country, and to contribute to knowledge development within the Swedish school system. The Swedish Schools Inspectorate's commission from the Swedish government is clearly indicated in this quotation: "Since the 2009/2010 school year, the Swedish Schools Inspectorate has been commissioned by the government to collect and review a selection of pupil solutions from national tests taken in primary, secondary and upper-secondary schools, in order to assess the uniformity of assessment and grading" (Swedish Schools Inspectorate, 2013a, p. 25). The Swedish Schools Inspectorate is also tasked with assessing whether the schools are working in accordance with current assessment and grading regulations. This mandate is referred to as enforced supervision, and is conducted in schools that have displayed significant discrepancies when it comes to the review of national tests, grading of national tests, and also when it comes to subjects and courses. The Supervisory Report (2013a) provides a description of the procedure: "Supervision has been conducted at 30 schools that have displayed great deviations from the review of the Swedish Schools Inspectorate, and/or which 
have had great discrepancies between the grades awarded for national tests and the final/course grades awarded" (Swedish Schools Inspectorate, 2013a, p. 5).

The Swedish Schools Inspectorate (2013c) is a compilation of the results from targeted inspections of working methods in 62 independent schools conducted all around Sweden in one day. The background of this inspection is that there has been a change of working methods within the Swedish school system over the last decades, and there has been much talk of flaws in the new system. Individual work has been given increasing room in the teaching, while classroom instruction and group projects have been pushed aside. "These flaws are expressed through working methods that do not provide the pupils with the guidance and incentives they need to further their knowledge acquisition" (p. 1). These observations formed the basis of the targeted inspection with the purpose of mapping three working methods: classroom instruction, group projects and individual projects. In addition, the study aims to assess how much teacher support the pupils would receive in respect of each working method.

After indications that many asylum-seeking children in Sweden are not attending school, and that they are not provided with the education they are entitled to, the Swedish Schools Inspectorate wanted to investigate the nature of these problems so that possible measures could be planned and implemented. This group also includes paperless children and children in hiding. The regulations state that asylum-seeking children are to be provided with an education on the same terms as other children in the same municipality. The Swedish Schools Inspectorate (2013b) states that the purpose of a targeted inspection in all the 290 Swedish municipalities is to "[...] evaluate whether the rights of asylum-seeking children to an education are met" (p. 7). This assignment is based on the Swedish Education Act (2010: 800) along with the Swedish Education Ordinance (SFS 2011: 185), which determine that the municipality in which an asylum-seeking child is living is obligated to provide a place for education no later than within a month after the child arrives in Sweden.

In the Swedish Schools Inspectorate (2014) report, the inspection focuses on municipal resource allocation and work against what they see as the negative effects of segregation within the preschool, compulsory school and recreation centre. An argument on behalf of conducting such an inspection is that international comparative studies have shown that the knowledge results in certain subjects have gone down for Swedish schools over the last decades, and that the gap between the top and bottom performances of the pupils have grown, both when comparing schools and groups of pupils. The auditing activities of the Swedish Schools Inspectorate are sanctioned by the wording of the Swedish Education Act (2010: 800) regarding the requirements for "[...] equal access to education, equal quality of education and compensatory education [...]" (p. 6).

The quality audit report entitled "The Schools' work with Democracy and Core Values" (Swedish Schools Inspectorate 2012) opens with the statement that the school's mission is double-sided, and reinforced by the new Education Act (2010: 800), and that it consists of conveying and establishing both knowledge and fundamental democratic values. To provide a background description of the audit purpose, the Swedish Schools Inspectorate provides an insight into how the democratic values can be understood and processed; it is about "educating aware and competent citizens who, in accordance with the ideals of democracy, are able to handle the knowledge and core values that form the cornerstones of Swedish society. The goal of the schools' work with democracy and core values is to promote democracy and counteract undemocratic expressions" (p. 6). The Inspectorate also issues a reminder that the school, according to the curricula, is to "[...] transfer fundamental values and to promote the pupils' learning, in order to thus prepare them for their future private and professional lives" (ibid.). In order to distinguish and highlight the development potentials focusing on democracy and core values, audits were carried out in 17 schools in 10 of the 290 Swedish municipalities, covering both the school and classroom level. The purpose of the audit has been described in the form of a general question: "Does the instruction and the communicative climate in compulsory school provide pupils with the right conditions to acquire civic skills in the form of fundamental values, knowledge and abilities that they, according to the governing documents, need to live and work in a democratic society?" (p. 13).

The Swedish school is managed by objectives and results, which means that there is a great amount of "[...] trust placed in the ability of the professionals, i.e., the headmasters and teachers, to seek out the best solutions for optimal goal-achievement by the pupils" (Swedish Schools Inspectorate 2010a, p. 6). The degree of freedom that management by objectives provides also entails obligations, such as the monitoring and evaluation of the pupil's knowledge development in relation to the national knowledge targets, which can generally be said to be the Swedish Schools Inspectorate's (2010a) purpose for this audit. In more specific terms, the audit is intended to "[...] assess whether schools where the headmaster is the highest authority have a functioning system for monitoring and evaluating the pupils' knowledge development, and whether they have a system for designing 
measures to improve knowledge results at the school" (p. 12). The quality audit is intended to "[...] improve the knowledge results of the pupils by clarifying flaws in quality and possible needs for development, so that schools, other operations and responsible authorities will be able to carry out improvements" (p. 5). The audit is also about "[...] influencing schools and their responsible authorities to become more functional in their management with regard to the aspects that have been reviewed" (p. 12). The scope of the audit includes 40 schools, the selection of which is based on criteria such as low knowledge results. The work of the schools is audited "[...] in its entirety across all years, in order to determine whether there is a 'common denominator' in the methods [...]"

Over the last years, issues concerning pupil safety have been in focus; the Swedish Schools Inspectorate mentions that in 2009, the Ombudsman for Children (BEO) and the Inspectorate received around 500 reports about degrading treatment, where the reporting party did not feel the school had taken appropriate action. The Swedish Schools Inspectorate (2010b) audit has been conducted from a pupil's perspective in order to "[...] contribute to the prevention of harassment and degrading treatment at the audited schools" (p. 5). The audit is thus about making concrete demands on the schools to work purposefully with promoting factors. The legislators' requirement for zero tolerance constitutes the departure point of the audit along with the UN Convention on the Rights of the Child. The selection consisted of 50 schools, of which several have previously received criticism for their work on core values, while others have been selected as presumed positive examples.

Nearly all Swedish teenagers start upper-secondary school (Swedish Schools Inspectorate, 2009), but nearly half of the pupils do not finish this part of their education with at least a passing grade. One in three will not get sufficient results to allow them to continue on to higher education, and one in four will not even take part in the instruction. The Swedish Schools Inspectorate refers to research, stating that "[...] half of the young people who have interrupted their education regret not completing it" (p. 6). The aim of this audit, which is presented in the Swedish Schools Inspectorate (2009), is for it to lead to "[...] operational improvements that leads to an increase in the proportion of pupils who complete their education, not only in the audited schools, but also in other schools under the same responsible authority, as well as in the country's upper-secondary schools in general, as they all share a similar mission" (p. 9). For the Swedish Schools Inspectorate (2009) quality audit report, the audit has therefore been focused on "[...] how schools and responsible authorities have taken on responsibility for ensuring that all pupils complete upper-secondary school, and thereby fulfilling their national education task." (p. 9). According to the Swedish Schools Inspectorate, the consequences of failures in the school system will result in "[...] costs, time waste and lost knowledge, for the individual as well as for society, as well as limited possibilities for further studies" (p. 8). The report shows that the audit selection consists of one upper-secondary school for each of the 27 responsible authorities across the country; 7 independent and 20 municipal ones. The Swedish Schools Inspectorate (2009) describes that the expected effects from the audit in the future is that responsible school authorities will come up with concrete measures for how to reduce the proportion of interrupted studies, and that it will be clear how they work with monitoring, evaluating and securing the results of any such measures taken.

In the next section, we present our own interpretation of the dialogue, or discourse, that testifies to the possibilities and obstacles of "The Aspirational School". In the intersection of the discourse between the Swedish Schools Inspectorate on the one side, and the people working in the schools on the other, a doxa becomes discernible that limits social actions by visualising what is to be considered acceptable and unacceptable, as well as natural and unnatural, in an effort to prepare young people for the role as citizens. This intersection shows the possible dispositions of our perception, thoughts and actions, i.e., the habitus deemed possible for those working in the schools as well as the Swedish Schools Inspectorate.

\subsection{The Aspirational School-Possibilities and Obstacles}

The Swedish Schools Inspectorate (2013a) clearly expresses the ambition that all pupils are to be graded on equal grounds. It is indicated that this is the responsibility of headmasters and teachers. "All pupils are to be graded on equal terms, and the grades may have multiple consequences for the pupil and their future" (p. 10) and "[...] headmasters must take on a greater responsibility for monitoring whether the school is implementing equivalent grading" (p. 22). In order to achieve this, the Swedish Schools Inspectorate feels it is important for the headmaster to promote cooperation with other schools, in order to create the best conditions for an equal grading. According to the teachers, the differences in grading may be a result of " $[\ldots]$ feeling insecure about the criteria for assessment and grading, and worrying about the equivalence of their grading compared to other schools" (p. 7). Audits have furthermore revealed that the schools "[...] do not know whether their grading is equivalent or not" (ibid.). Headmasters and teachers explain the differences between the national test grades and the final grades with "[...] the pupils feeling nervous when taking the test, or forgetting knowledge that they have already 
showed to their teachers on a different occasion" (ibid). The Inspectorate also quotes the pupils, who say that they are dissatisfied with the information regarding grading provided by the teachers, and that they at times have felt the assessment has been unfair. The Swedish Schools Inspectorate also provides positive examples of school teachers working together with grading: "[...] they feel secure in their assessment capabilities and their evaluation of the pupils' knowledge" (p. 7), which according to the Inspectorate increases the pupils' sense of satisfaction. Other perspectives that impact on the assessment and grading are also included in the Swedish Schools Inspectorate report. Above all, there is a reflection in reference to academic discussions regarding the question of whether the current education system can be seen as a marketable organisation, where the choice and independent school reforms can be described as a competitive system that may have contributed to grade inflation. Another aspect that this audit focuses on is market logic, as shown by the following quote: "[...] the responsible authorities connect the salaries of the school staff to the grade results of the pupils as well as to the evaluations of parents and pupils in various customer satisfaction surveys" (p. 24).

The Swedish Schools Inspectorate's targeted inspection, the Swedish Schools Inspectorate (2013b) regarding asylum-seeking children's right to an education, shows that the municipalities do not possess sufficient knowledge regarding the children who live in their area. "The inspection indicates that there is no reliable information regarding the number of asylum-seeking children in each municipality" (p. 4). This means that many asylum-seeking children, as well as those who are paperless or in hiding, do not always receive the education they are entitled to. "The municipalities are obligated to offer asylum-seeking children an education as soon as possible considering the individual circumstances of each child, but within one month at the latest" (p. 12). The fact that there is not sufficient data relating to the number of asylum-seeking children in the audited municipalities is considered by the Swedish Schools Inspectorate to be an obstacle to the municipalities fulfilling their obligations with regard to the rights of the children. The municipalities are of the opinion that the confidentiality applied between them and the Swedish Migration Board could be one of the reasons why the number of asylum-seekers is unknown to them. Other reasons for the municipalities being unable to offer education within the legislated time frame of one month is "temporary inflows of asylum-seeking children or the children being unable to start school for personal reasons" (p. 12). One municipality states that it has no upper-secondary school of their own. The inspection also shows that other reasons for the municipal failure to provide full-time education include "[...] a shortage of staff, but also that the municipalities have made the assessment [...]" that the children initially do not have the energy to go to school full-time (pp. 15-16). The municipalities are of the opinion that the legislative change, despite this, "[...] does not appear to cause a problem" (p. 20,) but that some municipalities are asking for "[...] national guidelines" (ibid.). There are concerns that "[...] will be used as a site to enforce refusal-of-entry or deportation decisions, and the municipalities have asked that the obligations of the individual schools be clarified" (p. 23). The Swedish Schools Inspectorate is also of the opinion that the municipalities must guarantee that the offer of an education is given also to children who have been granted permanent residence in Sweden.

The Swedish Schools Inspectorate (2013c) states that there has been a change of working methods within the Swedish school system over the last decades. Individual work has been given increasing room in the teaching, while classroom instruction and group projects have been pushed aside. The targeted inspection arrives at the conclusion that "These flaws express themselves as working methods that do not provide the pupils with the guidance and incentives they need to further their knowledge acquisition" (p. 5). The Swedish Schools Inspectorate feels that the responsible authorities and headmasters have to become better at follow-up. The inspection revealed a discrepancy between the inspector observations and the pupils' descriptions of their individual work. A large number of the interviewed pupils stated that they were happy with how the teachers and schools organise individual work. Lessons where the pupils can come and go as they please, surf online undisturbed on their mobiles or computers and talk to their friends may, according to the Swedish Schools Inspectorate (2013c) be an appreciated feature of the education for some pupils. The Swedish Schools Inspectorate partly connects this to lacking measures for change in the concerned municipalities. "Schools with weak quality management, lacking educational leadership, a failing pupil base or a high number of pupils needing additional motivation may not be able to achieve the necessary changes, as the pupils are seemingly happy" (p. 21). According to the pupils, the inspection did not go unnoticed; "[...] some of the teachers were much nicer when you were there... maybe you should be with us all the time?" (p. 18).

The quality audit that was conducted of the resource allocation of the municipalities and work against the negative effects of segregation on the school system (Swedish Schools Inspectorate, 2014) showed that "[...] an overwhelming majority of the audited municipalities could develop their work to counteract the negative effects of segregation within the preschool, compulsory school and recreation centre" (p. 6). It is also clear that the 
municipal work with follow-up and evaluation of their applied resource allocation systems has received criticism. "The audit has shown that 25 out of 30 municipalities need to develop and improve the follow-up and evaluation of their resource allocation systems, and the effects of these" (p. 8). The audit confirms earlier studies showing that the resource allocation carried out by the municipalities based on need is relatively cautious, and that "recreation centres and preschools are not as often included in the allocation" (p. 6). The Swedish Schools Inspectorate cites that education is to be equal in all school forms and recreation centres, no matter where in the country it is provided. "Three requirements set in the Education Act is equal access to education, equal quality of education and compensatory education" (p. 6). The audit also shows an awareness on the part of education politicians, headmasters, administrators and parents that there is a school segregation. "They all, without exception, attribute this segregation to the housing segregation. They often describe a tendency towards a reinforcement of this segregation, as the free school choice is used selectively, meaning that pupils with Swedish backgrounds, and whose parents have higher education, will take advantage of the free school choice to a greater extent" (p. 7). However, the Inspectorate points out that "[...] discussions regarding the possible effects of the free school choice on segregation have not been dealt with in this report" (p. 11). This is done while simultaneously highlighting the report of the Swedish National Agency for Education (2012: 374), which clearly indicates that the free choice and decentralisation reforms of the 1990s have most likely contributed to the reduced equivalence; housing segregation is thus not the sole cause. The Swedish Schools Inspectorate highlights positive examples of municipalities that have achieved a vital socioeconomic distribution, in accordance with the provisions of the Education Act, through a targeted structure to compensate for various variables such as "[...] education level of guardians, migration background, proportion of boys, financial aid, family compositions and small school supplements" (p. 14), which have been shown to influence the school results of the pupils. The municipalities that have not completed this type of redistribution force the schools to pay for mother tongue education and guidance counselling out of their own budget, which according to the Inspectorate could lead to pupils not receiving the assistance they are entitled to. Other recommendations from the Swedish Schools Inspectorate include physical measures in the form of school construction and altered area limitations, as well as language-oriented education (Swedish Schools Inspectorate, 2014).

The schools' work with democracy and core values (Swedish Schools Inspectorate, 2012) shows whether the educational and communication climate provide the pupils at the audited schools with the conditions to acquire the civic skills that they need in order to live and work as active citizens of a democratic society, according to the governing documents of the Swedish school system. The Swedish Schools Inspectorate notes that "[...] civic education features are seen in the instruction of all the observed subjects" (p. 44), but at the same time, the Inspectorate calls for "An increased awareness of what the democratic mission entails" (ibid.). The latter is intended to train pupils in abstract and critical thinking, and to translate experience from lessons and theoretical knowledge into practice. "The teachers also need to ensure that all pupils are really afforded the opportunity to express themselves and build up their democratic skills in the classroom" (p. 45). The report recommends an open and assessing dialogue; the deliberative approach. These dialogues are said to constitute "[...] the very core of the democratic assignment and the democratic process" (p. 46) in pursuit of a consensus. One challenge, according to the Swedish Schools Inspectorate, for all schools is to create secure and balanced study environments, where people's differences are valued. The Swedish Schools Inspectorate also recommends that a dialogue more inspired by theory of knowledge concepts is used to a higher extent in all subjects. The quality audit refers to earlier evaluations conducted by the National Agency for Education (2011d), which have shown that the work with core values carried out around the country has not been comparable, and they furthermore point out that [...] the work has consisted of preventive, reactive, increasingly instrumental and regulated measures $[\ldots]$ rather than a proactive promotion of the pupils' desire and ability to take independent and active responsibility, now and in the future, for our democracy" (p. 11).

Based on the completed audit of the schools' systematic work to improve the knowledge acquisition of the pupils, the Swedish Schools Inspectorate provides clear recommendations of what schools are to consider in their work with follow-up, evaluation and measures (Swedish Schools Inspectorate, 2010a). These recommendations have been summarised in some ten bullet points. These clearly indicate the responsibility of the headmaster, which is deemed to be "Keeping a clear delegation of responsibilities, which is known to all at the school, while the headmaster takes on the ultimate responsibility" (p. 38). The points also return to the ambition of an equal school, which is described as "Creating a common basis or model for the whole school system, which guarantees that the pupils' knowledge is assessed equally, and which makes it possible to aggregate and analyse the results" (p. 38). Focusing on the knowledge objective and having high expectations for all pupils is another recommendation. The Swedish Schools Inspectorate wants the goal of follow-up, measures and evaluation to be put in relation to 
the improvement of the pupils' knowledge results in school, and for this aim to permeate the school strategies for quality management and be expressed in daily activities and documentation. The Swedish Schools Inspectorate also calls for successful methods and strategies to be shared between school years and subjects (Swedish Schools Inspectorate, 2010a).

The Swedish Education Act (Chapter 14) and the Swedish Discrimination Act (Chapter 1-3) have the shared aim of "[...] protecting children and pupils from discrimination, harassment and violations" (Swedish Schools Inspectorate, 2010b, p. 13; Swedish Discrimination Act, 2009). The Swedish Schools Inspectorate supervises the adherence to the Education Act, while the Equality Ombudsman (DO) supervises the adherence to the provisions of the Swedish Discrimination Act. In its report on the schools' work in cases of harassment and violations, the Swedish Schools Inspectorate writes that the "zero-tolerance policy has not had the intended impact" (p. 16). The Inspectorate indicates that pupils have experienced adults harassing or violating their dignity, that harassment and violations are trivialised, that adults do not sufficiently instil trust, that routines are not always followed, and that the work with core values is not part of the schools' everyday activities. In its report, the Swedish Schools Inspectorate gives clear recommendations on how the above flaws could be corrected. For example, the Inspectorate recommends that "[...] the schools that do not have any routines for prevention and measures should immediately rectify this by establishing such" (p. 8). The report furthermore points out that the work with core values is often something that is done separate from the daily activities, meaning that "[...] this work is not always connected to the pupil's everyday lives, but is handled on occasions outside of the 'regular' teaching activities" (p. 26), which is also the perception of the pupils: "[...] we only talk about those things in Life Skills Training. Then we carry on as usual" (ibid.). The Life Skills Training classes can, according to the Inspectorate, give way to subject classes.

Based in the quality audit (2009), which highlights the challenge for Swedish upper-secondary schools to increase the number of pupils who complete their education, the Inspectorate gives clear recommendations to the responsible authority, headmaster, teacher and other staff. The audit shows that there is often a lack of general strategies to ensure that all pupils complete their education, and that initiatives and measures are seldom coordinated, and often more reactive than proactive. The Swedish Schools Inspectorate argues that the special measures required to prevent interrupted studies should be targeted at "[...] pupils of foreign backgrounds, pupils whose parents have less education, pupils in vocational and individual study programmes, and pupils in programmes where their gender is underrepresented" (p. 13). The Swedish Schools Inspectorate indicates that responsible authorities and headmasters are to ensure that this is done. The audit furthermore shows that the audited schools to a great extent lack a systematic quality management. Follow-ups are carried out, but are targeted more at the pupils' well-being than knowledge results. A point is also made that the study environment is disconnected from how a positive environment can create positive learning conditions. The adaptation of regular teaching activities to the conditions and needs of the individual pupil is considered underdeveloped and insufficiently prioritised. When the audited schools actually adapt the education to the pupils, it is often don through organisational differentiation, i.e., separation. The Inspectorate is of the opinion that instead of the special support that the pupil is entitled to, there is sometimes a transition into an individual or reduced programme, which could be described as excluding the pupil. It is rare that the pupils, for example, get to spend different amounts of time to reach the objectives, that the scope of their study plan is reduced or that they are given special support within or in connection to the regular activities. However, the Swedish Schools Inspectorate does give praise to certain sporadic measures taken, which can be described as having a more rational character, such as "[...] cooperation between subjects, early contact with the characteristic subjects of the study programme, the teacher approach, well-developed contact with guardians speaking another language, a higher number of teachers in programmes with poor results" (p. 12). The Inspectorate highlights the importance of collaboration between the compulsory and upper-secondary schools in order to achieve a fuller perspective, and lessen the "shock" of upper-secondary school through introduction weeks and opportunities for the pupils to get acquainted with the characteristic subjects at an early stage. Great variation has also been found in the way different teachers prioritise. In summary, this report indicates that extensive monitoring is conducted in several schools to detect pupils in need of special support, but that the forms of investigating the cause of this need, designing appropriate measures and evaluating the effects of these have not been sufficiently developed. The Inspectorate has identified a need to look beyond the shortcomings of the pupils and instead problematise the role of the responsible authorities, headmasters and not least the teachers, in order to give more pupils the right conditions to complete their upper-secondary education. 


\section{Discussion}

The Swedish Schools Inspectorate is an example of how the government can govern through performance and quality control. It can be said to have a top-down perspective, where the task is to inspect and audit the quality of delimited areas within the school; often with the aim of presenting measurable results. The results of our review is that the mission of the Swedish Schools Inspectorate, also in the analysed documents, corresponds well to the intentions formulated in the governing instruments of the Swedish school system. Focus during the inspections has been on highlighting whether the school knowledge objectives have been achieved, and whether the right of each child to an education is fulfilled. What we have shown in terms of empirical data is how the school inspectors have interpreted the voices of teachers, pupils and heads of school. In addition, this data also reflects the voices of the inspectors in their official capacities. Other than highlighting these aspects, the inspections have to a large extent been about suggesting concrete measures to eliminate the flaws discovered.

After reviewing and conducting a more in-depth analysis of the selected material, a new discursive field has emerged; the kidnapped independence. The fields are presented in the following section, after which we have made a few final comments.

\subsection{The Kidnapped Independence}

The inspections conducted are assumed to lead to improvements in the results of schools and pupils alike. Another assumption is that the collected data from the inspections are reliable and useful in communicating with the management of the country's schools. The results from the school inspections can be used as governing instruments, by monitoring the progress of different schools, but also by comparing different school forms and different schools. The inspections can also be said to have symbolic value; showing that the school activities are under control. The media has also successively become the messenger of school inspection results and other international measurements such as TIMSS and PISA. The audited material also provides examples of how market logic has penetrated the world of education. Teachers and pupils are viewed as products on a market where the teachers' salaries have become connected to the pupils' grades, as well as to the opinion of the parents and pupils expressed in terms of customer satisfaction. This can in turn be related to the fact that the Swedish Schools Inspectorate has its own objectives to achieve, such as carrying out a certain number of inspections. There may be cause to question whether the aspect of measurability is becoming more important at the cost of the school's mission to educate new citizens. Wahlström (2009) interprets the current developments as the productive force of the governing power fulfilling the NPM logic, which aims to move focus from resources and processes to performance and results. Biesta, Lawy and Kelly (2009) are of the opinion that civic education must begin with allowing young people a voice, and by taking their opinions seriously. Only on a few occasions is the voice of young people reflected in the audited documents. One example is when the teacher-pupil relationship is brought up in the course of an inspection, where a pupil comments that the teacher is behaving in a "nicer" manner.

The majority of the analysed reports show that the follow-up inspections of the Swedish Schools Inspectorate may lead to self-discipline, as headmasters and teachers will adjust their working methods to the audited aspects. The aspects that inspections and evaluations focus on will draw the attention of those audited towards these areas and questions. Sandahl and Bringe (2006), one of the few studies that deal with the work of the Swedish Schools Inspectorate, draw conclusions similar to those in the present study, and argue that the improvement areas indicated by the Inspectorate were already known to the school staff, and that the audit gave extra emphasis to the importance of taking measures with regard to these, which could mean that such measures are moved forward while other plans are given less priority. In a similar way to this study, the examination conducted by Sandahl and Bringes (2006) shows that the school inspections have been received with interest and positive reactions from many schools. The fact that the state has taken an interest in school activities has been appreciated; both studies also show that the schools have taken in the criticisms expressed. Ekholm and Lindvall (2008), on the other hand, strongly question the Swedish Schools Inspectorate, arguing that its work has had no effect and can therefore be seen as counter-productive. Our study has also shown that the state's faith in the inspections, controls and audits, along with the demands for development plans as an important part of Swedish school development can be questioned. Is it possible, for example, for a large number of inspectors with different preconceptions, backgrounds, experiences and values make comparable observations and similar assessments of the same phenomenon?

The inspections tend to instil a low level of independence in school activities by pointing out flaws and measures simultaneously, which in itself could lead to the judgement of the schools never being challenged, or worse, never being recognised. There are definitely risks to this procedure since, according to Kohn (1983), it could 
lead to a higher degree of dependence on an authority. The autonomy that forms the basis of a critical and interpretative approach, where there is room to reassess ideas and perceptions beyond the panoptical, disciplining regard; something that is often sought after by the inspector, will by this logic paradoxically enough become limited by the fact that such inspections are conducted. There is also the risk of the schools, in all good intention, being limited in terms of development potential. A critical and interpretative approach to the educational activities requires careful consideration of observations and experiences based on a long row of different perspectives, which according to Alvesson (2001) requires time, openness and tolerance of insecurity, not to mention creativity. People will act primarily based on their perception of reality and lessons learned through experience when attempting to realise a task based on their own preconceptions. An operation weighed down by authority will tend to promote, and even cultivate, an amateurish behaviour, including shallow/peripheral interpretations that leave no room for alternative ways of fulfilling the task at hand. This in itself leads to cries for help and guidance. The Swedish Schools Inspectorate thus constitutes its own entitlement, through the inspections, as well as what Bourdieu might call a defensive discourse to preserve its monopoly. The recognition of and trust in the profession and the school system as a whole would on the other hand indicate the opposite, and thereby replace control to a significant degree. Is there something in the reports that bring to mind recognition and trust? It appears that some statements, from those active in the schools as well as from the Swedish Schools Inspectorate, could be interpreted as civil disobedience. The Swedish Schools Inspectorate is an instrument for the government to ideologically influence the preschool and school, which is not always possible. A certain ambivalence can be discerned when it comes to the Swedish Schools Inspectorate attempting to uphold the thesis that housing segregation is the sole explanation for the increasingly segregated school, while in the next breath admitting that the free school choice has affected the educational equivalence.

This could be interpreted as the Swedish Schools Inspectorate giving the school a recognition, as equivalence cannot only be seen as a school problem, but as a result of conscious political decisions that also contribute to the need for a compensatory resource system at a municipal level, which must then also be audited. Putting on a pair of Habermas glasses, we could say that the systemic world is being influenced by the perspective of the lifeworld. The Swedish Schools Inspectorate also chooses to highlight the concerns of those active within the school that it will be used as a site to enforce refusal-of-entry or deportation decisions against asylum-seeking children. By visualising this aspect, the Swedish Schools Inspectorate indirectly directs criticism towards the current immigration policy, while recognising the operation simply by voicing the concerns of those active in the school; the Inspectorate could have chosen not to include this statement. The events again indicate the systemic world having been coloured by the lifeworld. Even if the Swedish Schools Inspectorate per se constitutes a dependency for the operation, there are still tendencies towards encouraging independent and critical thinking, both in terms of the school activities and the Swedish Schools Inspectorate's own approach as an auditing body commissioned by the government. Despite this encouragement of independent thought, the right conditions for autonomy will not be created as long as the audit by the Swedish Schools Inspectorate in itself tends to kidnap the independence of the schools. If we continue this train of thought and allow ourselves to ask whether this would be detrimental to the school activities, the answer tends to be affirmative, but could there be any other angles? We feel that other interpretations could be possible. What the Swedish Schools Inspectorate indicates as flaws, but also as benefits, could at a closer inspection be seen as an expression of the concrete, disciplinary action of the governing powers. Schools are indicated in the reports for their shortcomings, and alternative actions are suggested. In this case, the powers could paradoxically enough, and in accordance with Foucault's ideas, be seen as a productive force as this process could give new energy to the schools and inspire them to start forming counter-strategies. Such strategies could initiate a remodelling towards a different "school identity". Since the defensive, monopolising discourse has now been questioned, other dispositions may appear that leads to an altered school habitus beyond the discursive dominance of the Swedish Schools Inspectorate.

\section{Concluding Remarks}

The purpose of this article has been to visualise and give examples of how the Swedish schools have interpreted their mission of educating young people and preparing them for the role of active citizens. More specifically, we were interested in how the "good" or "aspirational" school is presented in the reports published by the Swedish Schools Inspectorate. Based on an interpretation of the Swedish Schools Inspectorate's audits, we wanted to reconstruct the discourses that emerge regarding the aspirational school; the mission of which is to support young people in their transformation into active citizens.

The battle of what is to be considered the symbolic and legitimate capital for the school field is thus waged between the auditors and the auditees; the question becomes who will present the most genuine interpretation of how learning and education will prepare young pupils for their role as active citizens. The results indicate that 
the aim of improving the pupils' knowledge results are a high priority for the Inspectorate, as is the goal to ensure all children and pupils' equal rights to a good education in a safe and stimulating environment, and to develop their civic skills. The analysed reports show that the inspections have revealed inadequate fulfilment of all these goals. Whether school inspections can functionally contribute to fulfilling the goal of educational equality, improving the knowledge of Swedish pupils and helping them develop into good citizens is debatable. On the one hand, the auditing function in itself constitutes a threat to the school operations developing a judgement that would allow for reflections beyond the concept of effectiveness, and on the other hand the audits may, paradoxically enough, liberate the strength to question the discursive dominance of the Swedish Schools Inspectorate, shaped by systemic world logic, and thereby achieve an independent development.

\section{References}

Alvesson, M. (2002). Kommunikation, makt och organisation: kritiska tolkningar av ett informationsmöte $i$ ett företag [Communication, power and organisation: critical interpretations of a company information meeting]. (2nd ed.). Stockholm: Norstedts juridik.

Alvesson, M., \& Sköldberg, K. (1994). Tolkning och reflektion. Vetenskapsfilosofi och kvalitativ metod [Interpretation and reflection. Theory of knowledge and qualitative methods]. Lund: Studentlitteraur.

Andersen, H. (2007). Jürgen Habermas. In I. H. Andersen, \& L. B. Kaspersen (Eds.), Klassisk och modern samhällsteori [Classical and modern social theory] (pp. 279-295). Lund: Studentlitteratur.

Ball, S. (1994). Education reform. A critical and post-structural reform. Buckingham: Open University.

Bergström, G., \& Boréus, K. (2000). Textens mening och makt. Metodbok i Samhällsvetenskaplig textanalys. [The meaning and power of texts. Methodology handbook for social science text analysis]. Lund: Studentlitteratur.

Biesta, G., Lawy, R., \& Kelly, N. (2009). Education, Citizenship and Social Justice. Understanding young people citizenship learning in everyday life: The role of contexts, relationships and dispositions. Education, Citizenship and Social Justice, 4, 5. http://dx.doi.org/10.1177/1746197908099374

Bourdieu, P. (1973). The three forms of theoretical knowledge. Social Science Information, 12, 53-80. http://dx.doi.org/10.1177/053901847301200103

Broady, D. (1991). Sociologi och epistemologi: om Pierre Bourdieus författarskap och den historiska epistemologin [Sociology and Epistemology: on the authorship of Pierre Bourdieu and the historical epistemology]. Diss. Stockholm: HLS förslag.

Broady, D. (1996). Politics of popular identity. Understanding recent populist movements in Sweden and the United States. PhD. Lund: University Press.

Brunmark, Å. (2010). Den formella skoldemokratins roll för medborgarfostran och elevinflytande. Utbildning \& Demokrati, 19(2).

Carlbaum, S. (2012). Blir du anställningsbar/lille/a vän? Diskursiva konstruktioner av framtida medborgare $i$ gymnasiereformer 1971-2011 [Will you be employable when you grow up? Discursive construction of future citizens in upper-secondary school reforms 1971-2011] ( Doctoral thesis Umeå: Umeå universitet).

Carlsson, L. (2006). Medborgarskap som demokratins praktiska uttryck i skolan - diskursiva konstruktioner av gymnasieskolans elever som medborgare [Citizenship as the practical expression of democracy in school discursive constructions of upper-secondary pupils as citizens]. Acta Wexionensia. No. 84/2006. Pedagogik. Växjö: Växjö University Press.

Code of Statutes of the National Agency for Education. (2011). Grundföreskrift [Fundamental regulation]. Stockholm: Swedish National Agency for Education.

Diskrimineringslag. (2009). Diskrimineringslag [Swedish Discrimination Act: applicable wording from 01/01/2009]. Stockholm: The Swedish Association of Local Authorities and Regions.

Ekholm, M., \& Lindvall, K. (2008). Skolinspektioner-i tid och otid. Pedagogisk forskning i Sverige, 13, 41-58.

Ekman, T. (2007). Demokratisk kompetens. Om gymnasiet som demokratiskola [Democratic competence. On the upper-secondary school as a school of democracy]. Department of Political Science at the University of Gothenburg. Göteborg: Göteborgs universitet.

Fairclough, N. (1992a). Discourse and Social Change. Cambridge: Polity Press.

Fairclough, N. (1992b). Critical Discourse Analysis. A critical Study of Language. London: Longman. 
Fiehn, J. (2007). Post-16 Citizenship in School Sixth Forms: An Introduction to Effective practice. London: Quality Improvement Agency.

Foucault, M. (1987). Övervakning och straff: fängelsets födelse [Discipline \& Punish: The Birth of the Prison]. Lund: Archives.

Foucault, M. (1993). Diskursens ordning: installationsföreläsning vid Collège de France den 2 december 1970 [The Order of Discourse: Inaugural lecture at Collège de France delivered on 2 December 1970]. Stockholm: B. Östlings bokförl. Symposion.

Gordon, T., Lahelma, E., \& Beach, D. (2003). Marketisation of Democratic Education: Ethnographic Insights. In I D. Beach, T. Gordon, \& E. Lahelma (Eds.), Democratick Education: Ethnographic Challenges. London: Tufnell Press.

Gustavsson, B. (Ed.). (2004). Kunskapande metoder inom samhällsvetenskapen [Methods of knowledge acquisition in social sciences]. Lund: Studentlitteratur.

Habermas, J. (1984). The theory of communicative action, Vol. I. Boston: Beacon.

Habermas, J. (1996). Kommunikativt handlande: texter om språk, rationalitet och samhälle [Communicative actions: Text and language, rationality and society]. (2nd ed.). Göteborg: Daidalos.

Hartsmar, N., \& Liljefors, P. B. (Eds.) (2013). Medborgerlig bildning: demokrati och inkludering för ett hållbart samhälle [Civic education: democracy and inclusion for a sustainable society] (1st ed.). Lund: Studentlitteratur.

Hellspong, L. ( 2001). Metoder för brukstextanalys [Methods for textual analysis]. Lund: Studentlitteratur.

Järvinen, H. (2007). Pierre Bourdieu. In I. H. Andersen, \& L. B. Kaspersen (Eds.), Klassisk och modern samhällsteori [Classical and modern social theory] (pp. 263-278). Lund: Studentlitteratur.

Kjørholt, A. (2004). Childhood as a social and symbolic space: Discourses on children as social participants in society (Doctoral theses, Trondheim: Norwegian Center for Child Research, NTNU).

Kohn, M. (1983). Arbetets komplexitet och den vuxna personligheten. In I. G. Aronsson (Ed.), Arbetets krav och mänsklig utveckling [The demands of professional life and human development]. Stockholm: Prisma.

Lister, R. (2007). Inclusive citizenship: Realizing the potential. Citizenship Studies, 11(1), 49-61. http://dx.doi.org/10.1080/13621020601099856

Lister, R. (2007a). Why citizenship: Where, when and how children? Theoretical inquires in Law, 8(2), 693-718.

Månsson, P. (Ed.). (1995). Moderna samhällsteorier, traditioner riktningar teoretiker [Modern social theories, traditional approaches and theorists]. Smedjebacken: Rabén Prisma.

Olsson, Å. (2013). Barns levda medborgarskap. En studie av barns vardagskunskaper om olycksrisker och säkerhet [The citizenship of children. A study of children's day-to-day knowledge of risks and safety] (Doctoral thesis, Karlstad University).

Rönnlund, L. (2013). Elevinflytande i en skola i förändring [Pupil influence on a school in change]. Utbildning \& Demokrati, 22(1), 65-83.

Sandahl, R., \& Bringle, S. (2006). Skolverkets utbildningsinspektion-ger den några effekter [The National Agency for Education school inspection-is it effective]? Stockholm: The Swedish National Financial Management Authority

Sandström, K. M., \& Stier, J. (2008). Citizenship education: Forming cultural identity in five European countries. (1st ed.). Malmö: Gleerup.

Sjöberg, L. (2009). Skolan och den "goda" utbildningen—för ett konkurrenskraftigt Europa [The school and the "good" education—for a competitive Europe]. Utbildning och Demokrati, 18(1), 33-58.

Skolinspektionen. (2009). Varannan i mål. Om gymnasieskolors (o) förmåga att få alla elever att fullfölja sin utbildning [One in two to the finish line. On the (in)ability of the upper-secondary schools to get their pupils to complete their education]. Quality Audit (No.1). Stockholm: The Swedish Schools Inspectorate.

Sulke, F. (2007). Young people and Active European Citizenship. Strengthening Opportunities for Citizenship education on a Local level: Examples from practice under Difficult Conditions. Freie Universität Berlin. Berlin Working paper on European Integration, N2 2. Retrieved May 23, 2008, from http://www.fu-berling.de/europa 
Swedish Code of Statutes (SFS 209: 1521). (1985). Lag om ändring i skollagen (1985: 1100) [Swedish Education Act]. Stockholm: Nordstedts juridik.

Swedish Code of Statutes. (SFS 2011: 185). (2011). Skolförordningen [Swedish Education Ordinance]. Stockholm: Nordstedts juridik.

Swedish Education Act. (2010). Skollagen (2010: 800): med Lagen om införande av skollagen (2010: 801) [Swedish Education Act (2010:800)]. Stockholm: Norstedts juridik.

Swedish National Agency for Education Report. (2012). Likvärdig utbildning i svensk grundskola? En kvantitativ analys av likvärdighet över tid [Equal education in the Swedish compulsory school? A quantitative analysis of equality over time] (Report 374). Stockholm: Swedish National Agency for Education.

Swedish National Agency for Education. (2010). Läroplan för förskolan Lpfö 98 [Preschool curriculum Lpfö 98]. Stockholm: Swedish National Agency for Education.

Swedish National Agency for Education. (2011a). Läroplan för grundskolan, förskoleklassen och fritidshemmet 2011 [Curriculum for the compulsory school system, the preschool class and the recreation centre Lp11]. Stockholm: Swedish National Agency for Education.

Swedish National Agency for Education. (2011b). Läroplan, examensmål och gymnasiegemensamma ämnen för gymnasieskola 2011 [Curriculum for the upper secondary school Gy11]. Stockholm: Swedish National Agency for Education.

Swedish National Agency for Education. (2011c). Skolan och medborgarskapandet, En kunskapsöversikt [The school and the citizenship; A knowledge review]. Swedish National Agency for Education. Stockholm: Swedish National Agency for Education.

Swedish National Agency for Education. (2011d). Redovisning av uppdrag om skolans värdegrund [Account of the work with core values in the schools] (Ref. no. U 2009/2848/S). Stockholm: Swedish National Agency for Education.

The Swedish Schools Inspectorate. (2010a). Arbetar skolor systematiskt för att förbättra elevernas kunskapsutveckling? Quality Audit (2010: 10). Stockholm: The Swedish Schools Inspectorate.

The Swedish Schools Inspectorate. (2010b). Skolors arbete vid trakasserier och kränkande behandling. Quality Audit (2010: 1). Stockholm: The Swedish Schools Inspectorate.

The Swedish Schools Inspectorate. (2012). Skolornas arbete med demokrati och värdegrund. Quality Audit (2012: 9). Stockholm: The Swedish Schools Inspectorate.

The Swedish Schools Inspectorate. (2013a). Tillsyn av bedömning och betygsättning. Med fokus på skolor med stora avvikelser i förhållande till skolinspektionens omrättning och i relationen mellan nationella prov och slutbetyg (Supervisory Report). Stockholm: The Swedish Schools Inspectorate.

The Swedish Schools Inspectorate. (2013b). Asylsökande barns rätt till utbildning. Nationell sammanställning från flygande inspektion. Targeted inspection (Ref. no. 402-2013: 2272). Stockholm: The Swedish Schools Inspectorate.

The Swedish Schools Inspectorate. (2013c). Lärarstöd och arbetsformer i fristående gymnasieskolor. Sammanställning av resultat efter flygande inspection. Targeted inspection (Ref. no. 402-2013: 189). Stockholm: The Swedish Schools Inspectorate.

The Swedish Schools Inspectorate. (2014). Kommunernas resursfördelning och arbete mot segregationens negativa effekter $i$ skolväsendet [Municipal resource allocation and work against the negative effects of segregation in the swedish school system]. Quality Audit (2014: 1). Stockholm: The Swedish Schools Inspectorate.

Thornberg, R., \& Thelin, K. (Eds.). (2011). Med ansiktet vänt mot Europa. Perspektiv på Skolutveckling [Facing Europe. Perspectives on school development]. Stockholm: The Swedish Teachers' Union, the Swedish National Agency for School Improvement/Swedish National Agency for Education, the Swedish Association of School Principals and Directors of Education.

Winther, J. M., \& Phillips, L. (2000). Diskursanalys som teori och metod [Discourse analysis in theory and method]. Lund:Studentlitteratur. 


\section{Appendix 1}

\section{Analysed documents}

\section{Supervisory report}

Supervisory report (2013: 01). (2013a). Tillsyn av bedömning och betygsättning [Supervision of assessment and grading]. Swedish Schools Inspectorate.

\section{Targeted inspections}

Targeted inspection (Ref. no. 402-2013: 2272). (2013b). Asylsökande barns rätt till utbildning [Asylum-seeking Children's Right to an Education]. Swedish Schools Inspectorate.

Targeted inspection. (2013c) Lärarstöd och arbetsformer i fristående gymnasieskolor [Teacher support and working methods in independent upper-secondary schools] (Ref. no. 40-2013: 180). (Swedish Schools Inspectorate).

\section{Quality audits}

Quality Audit (2014: 1). (2014). Kommunernas resursfördelning och arbete mot segregationens negativa effekter $i$ skolväsendet [Municipal resource allocation and work against the negative effects of segregation in the Swedish school system]. Swedish Schools Inspectorate.

Quality Audit (2012: 9) (2012). Skolornas arbete med demokrati och värdegrund [The Schools' work with Democracy and Core Values]. Swedish Schools Inspectorate.

Quality Audit (2010: 10). (2010a). Arbetar skolor systematiskt för att förbättra elevernas kunskapsutveckling? [Do the schools work systematically to improve the knowledge acquisition of the pupils?] Swedish Schools Inspectorate.

Quality Audit (2010: 1). (2010b). Skolors arbete vid trakasserier och kränkande behandling [The schools' work in cases of harassment and violations]. Swedish Schools Inspectorate.

Quality Audit (2009: 1). (2009). Varannan i mål. Om gymnasieskolors (o) förmåga att få alla elever att fullfölja sin utbildning [One in two to the finish line; On the (in)ability of the upper-secondary schools to get pupils to complete their education]. Swedish Schools Inspectorate.

\section{Copyrights}

Copyright for this article is retained by the author(s), with first publication rights granted to the journal.

This is an open-access article distributed under the terms and conditions of the Creative Commons Attribution license (http://creativecommons.org/licenses/by/3.0/). 